\title{
Study of some biological aspects of the Nile Carp, Labeo niloticus (Pisces, Cyprinidae) from Khashm El-Girba Reservoir and Atbara River; Eastern Sudan: II, length- weight relationship, condition factor and age structure
}

\author{
Mutasim Yousif Mohamed Abdalla ${ }^{1 *}$, Abuelgasim Ibrahim Abdelhalim ${ }^{2}$ \\ and Ahmed El Bedawi Adam ${ }^{3}$
}

\author{
${ }^{1}$ Khashm El-Girba Fisheries Research Station, Fish and Aquatics Research Centre, Animals Resources Research \\ Corporation - Sudan. \\ 2Department of Zoology, Faculty of Science, University of Khartoum, Sudan. \\ ${ }^{3}$ Fisheries and Aquaculture Consultant, Ministry of Animal Resources and Fisheries, Khartoum State, Sudan.
}

${ }^{\star}$ Corresponding author. Email: mutasim.emy@gmail.com; ORCID ID: 0000-0002-7219-7717.

Copyright (@ 2021 Abdalla et al. This article remains permanently open access under the terms of the Creative Commons Attribution License 4.0, which permits unrestricted use, distribution, and reproduction in any medium, provided the original work is properly cited.

Received 15th May, 2021; Accepted 14th June, 2021

\begin{abstract}
This study was undertaken to assess the length-weight relationship, condition factor and age structure, of the Nile carp, Labeo niloticus, in Khashm El-Girba reservoir and Atbara River, Sudan, from December 2015 to November 2016. Samples of fish were collected bi-monthly from three locations, namely; Um Aswad (Atbara River), El-Remila and El-Monaba (Khashm El-Girba reservoir), using beach seine nets of 1.2, 4.0 and $7.0 \mathrm{~cm}$ stretched mesh. Out of a total number of 1,190 specimens of $L$. niloticus collected from the three sampling sites, 189 specimens were randomly selected to determine age. The relationship between length and weight indicated negative allometric growth pattern in all three locations, where the slope (b) of the $(L W R)$ was highly significant $(p<0.001)$ and ranged from 2.178 to 2.885 . The mean condition factor $(\mathrm{K})$ varied monthly in the three locations with values ranging from 1.671 in Um Aswad (Atbara River) to 2.548 in El-Monaba (reservoir). Although the age of $L$. niloticus ranged from $0+$ and $3+$ years, yet, most of the studied fish are between age $0+$ and $1+$.
\end{abstract}

Keywords: Age structure, Atbara River, condition factor, Khashm El-Girba reservoir, Labeo niloticus, length-weight relationship.

\section{INTRODUCTION}

The main freshwater fisheries in Sudan are located in the River Nile and its tributaries, major dam reservoirs and man-made lakes. The Atbara River forms one of the five sub-basins of the Nile system within Sudan borders. Lake Khashm El Girba was formed on the eastern part of Sudan as a result of the construction of Khashm El Girba Dam across the Atbara River in 1964, creating a lake that supports a seasonal artisanal fishery (October - July) (Salih 1995 and FAO, 2014).

Four commercial species of genus Labeo occur in the Sudan; viz. L. niloticus Forskal, 1775, Labeo horie Heckel, 1846, Labeo coubie Riippell, 1832, and Labeo forskalii
Riippel, 1835, which is a rare species and occurs mainly on rocky places. The four species are capable of growing to about 2.0 feet standard length and over $4.0 \mathrm{~kg}$ in weight (Abu Gideiri, 1984).

Knowledge of length-weight relationship (LWR) is an important tool in the management of the resource and determining the exact age of reproduction, growth, rate, over fishing and under fishing (El-Azrag, 1981). Moreover, it can provide information about the, general health of the fish, habitat conditions, life history, fish fatness and wellbeing and morphological characteristics of the fish (Schneider et al., 2000, Froese, 2006). The successful 
management of small- scale fisheries requires the use of biometric data collected in the field, in order to transform them into suitable indicators. Fish can attain either isometric growth, negative allometric growth or positive allometric growth. Isometric growth is associated with no change of body shape as an organism grows. Negative allometric growth implies the fish becomes more slender as it increase in weight, while positive allometric growth implies the fish becomes relatively stouter or deeperbodied as it increases in length (Riedel et al., 2007). However, the growth process of freshwater fishes can differ in the same species dwelling over diverse locations, influenced by numerous biotic and abiotic factors.

An additional important biometric tool is the relative condition factor $(\mathrm{K})$ which can be derived from the lengthweight relationship (Le Cren, 1951). Condition factor shows the degree of wellbeing of the fish in their habitat, and measures the deviation of an organism from the average weight in a given sample. It assess the suitability of a specific water environment for growth of fish (Yilmaz et al., 2012, Mensah, 2015). An overall fitness for fish species is assumed when $(K)$ values are equal or close to one. When the value of condition factor is higher, it means that the fish has attained a better condition. Ahmed et al. (2011) used the condition factor (K) of L. niloticus in Khashm El-Girba reservoir to assess the fatness of this species, and found that it ranged from $1.595 \pm 0.912$ to $2.536 \pm 0.070$. Obeida (2010) reported that the condition factor of $L$. niloticus ranged between 2.401 to $1.268 \pm 1.871$ in El hashaba, and 3.495 to $1.302 \pm 1.951$ in Kosti, and 3.856 to $1.112 \pm 1.836$ in El Nuzul. While Karar et al. (2017) recorded mean condition factor for L. niloticus of 1.4216 , indicating good physiological condition of the fish. However, the condition factor of fish can be affected by a number of factors such as stress, sex, season, availability of food, and water quality parameters (Khallaf et al., 2003).

Several investigators studied the habitat, food and feeding, age and growth and some aspects of the population dynamics of $L$. niloticus in Jebel Aulia dam reservoir, Khashm El-Girba reservoir and Atbara River and the River Nile in Sudan (Ahmed, 1978; El-Moghraby et al., 1993; Bailey, 1994; El- Kasheif et al., 2007, Salih, 1995; Abdalla, 2018; Abdalla et al., 2020). Nin (1992) studied age and growth of fish to show changes in fish population and body size caused by fishing mortality rate.

Thus, the aim of this study was investigate the lengthweigh relationship condition factor and age structure of Labeo niloticus from Atbara River and Khashm El-Girba reservoir in order to assess its growth pattern, fitness and well-being, and consider seasonal variations of age of this species in the study area.

\section{MATERIAL AND METHODS}

\section{Study area}

The study area comprised three sampling sites, one site in
Atbara River (downstream) and two sites in Khashm ElGirba reservoir (upstream). Sampling sites were located according to the coordinates determined by using GPS (Garmin 62sc), as shown in Table1 and Figure 1.

\section{Collection of samples}

Samples of L. niloticus were collected bi-monthly during the period December 2015 to November 2016. Three beach seine nets were used with stretched mesh size of $1.2,4.0$ and $7.0 \mathrm{~cm}$; of length 32.0 .78 .0 and $88.0 \mathrm{~m}$, and of depth 1.7, 2.2 and $4.7 \mathrm{~m}$ respectively. Fish were identified to the species level according to Abu Gideiri (1984) and Bailey (1994).

\section{Morphometric measurements}

Total length (TL) of fish was measured to the nearest 0.1 $\mathrm{cm}$ from the tip of snout to end of the upper lobe of the caudal fin, and standard length (SL) from the tip of the snout to the flexure between caudal peduncle and caudal fin, using a measuring board. Body weight (BW) was recorded to the nearest $0.1 \mathrm{~g}$ using a digital balance (SF$400 \mathrm{~A})$. All measurements of the collected samples of $L$. niloticus were taken at the sampling sites.

\section{Biological studies}

\section{Length-weight relationship}

The relationship between length and weight of $L$. niloticus was calculated according to the equation $\mathrm{W}=\mathrm{a} \mathrm{Lb}$ (Bagenal and Tesch, 1978).

Where: $W=$ total weight of fish $(\mathrm{g}), \mathrm{L}=$ standard length of fish $(\mathrm{cm}), a=$ constant and $b=$ the regression coefficient, estimated by converting the logarithmic linear regression of the transformed equation according to Sparre and Venema (1992) as follows:

$\log (W)=\log (a)+b \log L$

Data analysis was carried out using Past Statistical Package version 3.14.

\section{Condition factor (Fulton's factor) (FCF)}

Condition factor $(\mathrm{K})$, is calculated according to the formula:

$\mathrm{K}=\frac{W}{L b} \times 100$

Where; $\mathrm{W}=$ total weight of the fish in grams and $\mathrm{L}=$ the standard length of the fish in $\mathrm{cm}$.

The value of (b) usually ranges from 2.5 to 4.0 for mature freshwater fish. 
Table 1. Estimated distance and coordinates of sampling sites in relation to Khashm El-Girba Fisheries Research Station.

\begin{tabular}{llccc}
\hline Site & location & Distance $(\mathbf{k m})$ & Coordinate (GPS) & Elevation (ft.) \\
\hline Um Aswad & Downstream & 2.77 & $14^{\circ} 85^{\prime} 23.03^{\prime \prime} \mathrm{N}-35^{\circ} 45^{\prime} 48.86^{\prime \prime} \mathrm{E}$ & 1440 \\
El-Remila & Upstream & 6.57 & $14^{\circ} 45^{\prime} 3.89^{\prime \prime} \mathrm{N}-35^{\circ} 52^{\prime} 42.69^{\prime \prime} \mathrm{E}$ & 1549 \\
Al-Monaba & Upstream & 10.10 & $14^{\circ} 51^{\prime} 85.17^{\prime \prime} \mathrm{N}-35^{\circ} 52^{\prime} 37.27^{\prime \prime} \mathrm{E}$ & 1550 \\
\hline
\end{tabular}

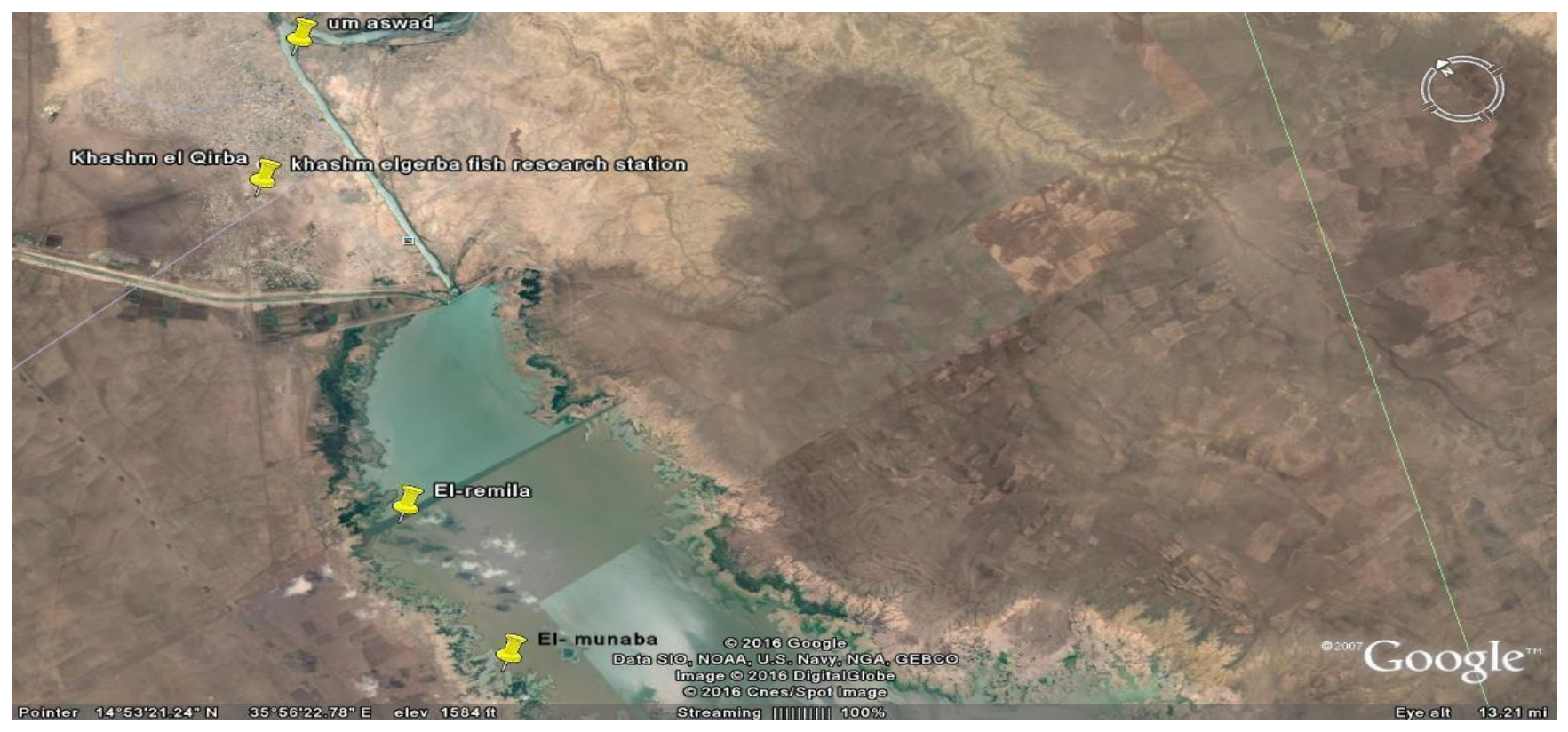

Figure 1. Map of sampling sites at Khashm El-Girba reservoir and Atbara River (source Google earth programme, 2016).

\section{Age}

Age of $L$. niloticus was estimated by dissecting the five anterior- most vertebrae of the fish, as they are best developed in freshwater fishes. The vertebrae were then removed, boiled and cleaned using a plastic brush, dried for 3 days, and kept in paper envelopes, with date of capture, area of collection, total and standard length and weight. Age of fish was read with the help of a magnifying lens (Nin, 1992).

\section{Data analysis}

Data was analyzed using the statistical package (Past statistical package version 3.14) to obtain liner regression and correlation and Microsoft office Excel 2007 to calculate average and standard deviation.

\section{RESULTS}

\section{Length - weight relationship}

In the present study, the plot of standard length of $L$. niloticus against the corresponding weight yielded logistic curve, which was straightened by logarithmic transformation of data. The slope (b) of the length-weight relationship of $L$. niloticus was highly significant $(p<0.001)$, indicating negative allometric growth pattern which ranged from 2.178 to 2.885 in the study area (Figure 2, Table 2).

\section{Condition factor}

The average condition factor calculated for L. niloticus recorded values of $1.671 \pm 0.273,1.953 \pm 0.644$ and 2.548 \pm 0.516 in Um Aswad, El- Remila and El-Monaba sampling sites respectively. Relatively high values of condition factor were recorded during April to July $(2.038 \pm 0.775$ $2.333 \pm 0.640$ ) at El-Remila site (upstream). High values of condition factor were also recorded at El-Monaba site (upstream) during February to June $(2.205 \pm 0.431$ $2.601 \pm 0.481)$ as well as during periods from July to October, indicating good growth of this species upstream of Khashm El-Girba reservoir. However, the overall mean condition factor $(\mathrm{K})$ ranged from 1.671 to 2.548, $1.953 \pm 0.644$ and $2.548 \pm 0.516$ in Um Aswad, El-Remila and El-Monaba sampling sites respectively (Table 3). 
Table 2. Linear fit of length -weight relationship of L. niloticus at Khashm El-Girba reservoir and Atbara River during the study period (Dec 2015- Nov 2016).

\begin{tabular}{llcccc}
\hline Site & \multicolumn{1}{c}{ Equation } & No. & Value of (b) & Value of (a) & $\boldsymbol{r}$ \\
\hline Um Aswad & $\log (\mathrm{W})=1.496+2.824 \log \mathrm{SL}$ & 574 & 2.824 & 1.496 & 0.920 \\
El-Remila & $\log (\mathrm{W})=1.567+2.885 \log \mathrm{SL}$ & 376 & 2.885 & 1.567 & 0.974 \\
El- Monaba & $\log (\mathrm{W})=0.649+2.178 \log \mathrm{SL}$ & 240 & 2.178 & 0.649 & 0.527 \\
\hline
\end{tabular}

Where: $(b)$ is the slope, and (a) is intercept of linear regression, $r$ correlation coefficient.
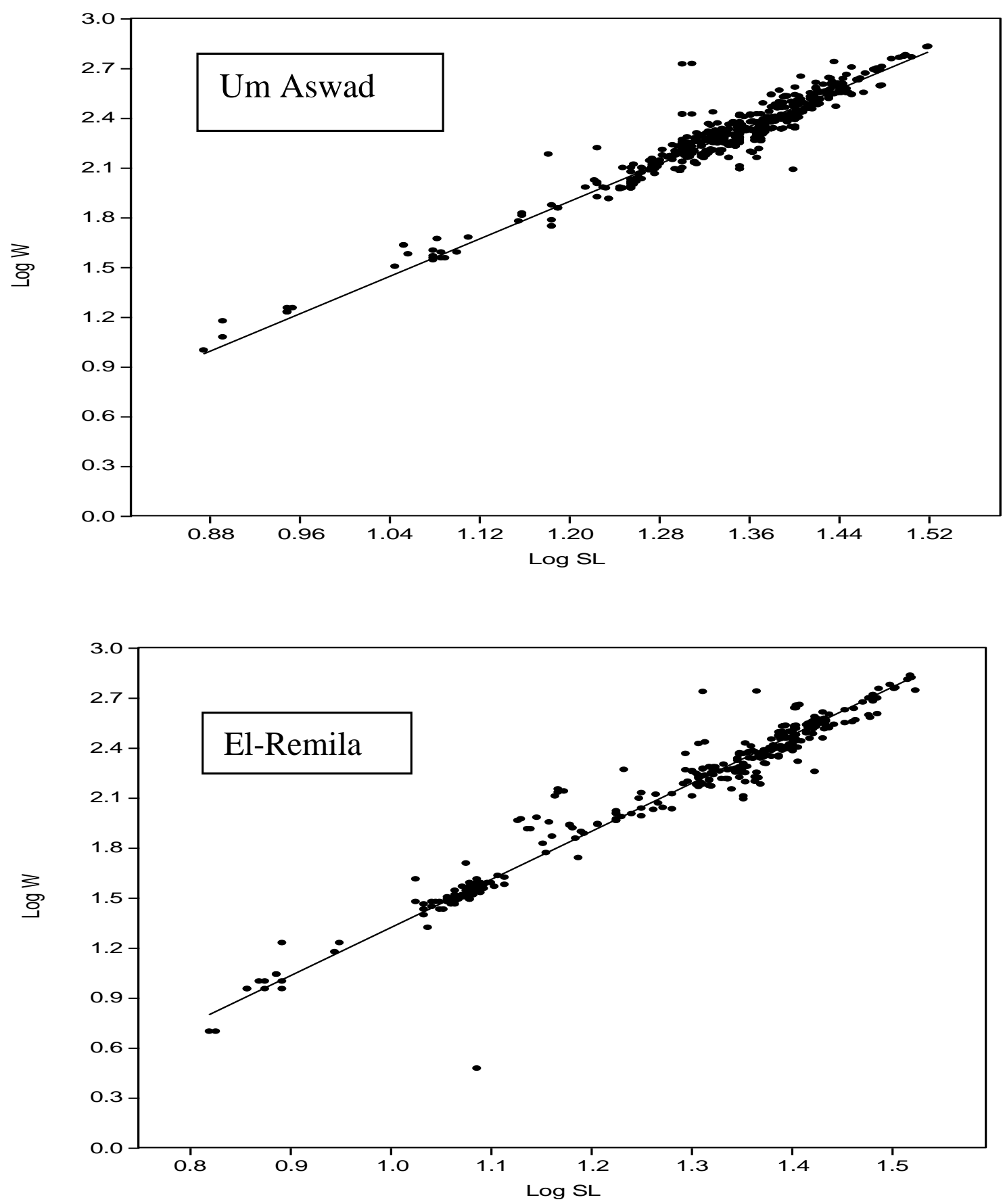

Figure 2. Linear fit of length-weight relationship of L. niloticus in Um Aswad (Atbara River) and El-Remila and El-Monaba (reservoir). 


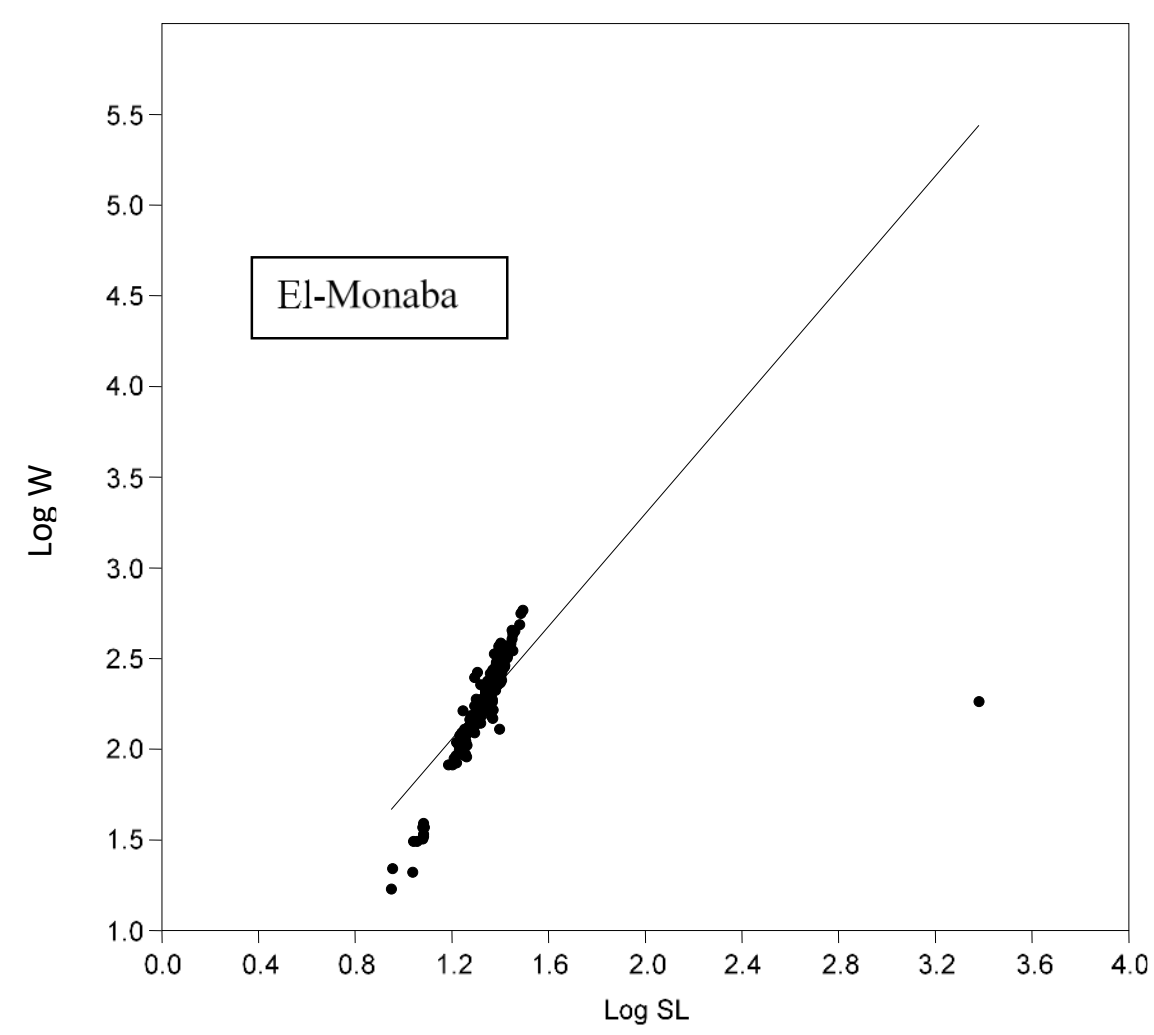

Figure 2. Contd.

Table 3. Average condition factor of $L$. niloticus in the study area during the period (Dec 2015- Nov 2016).

\begin{tabular}{lccc}
\hline Months & Um Aswad & El-Remila & El-Monaba \\
\hline Dec-15 & $1.549 \pm 0.193$ & $1.802 \pm 0.523$ & 1.155 \\
Jan-16 & $1.652 \pm 0.211$ & $1.860 \pm 0.714$ & 1.650 \\
Feb-16 & $1.742 \pm 0.357$ & $1.872 \pm 0.750$ & $2.205 \pm 0.431$ \\
Mar-16 & $1.689 \pm 0.220$ & $1.898 \pm 0.746$ & $2.372 \pm 0.344$ \\
Apr-16 & $1.699 \pm 0.305$ & $2.038 \pm 0.775$ & $2.551 \pm 0.621$ \\
May-16 & $1.692 \pm 0.323$ & $2.083 \pm 0.575$ & $2.587 \pm 0.545$ \\
Jun-16 & $1.678 \pm 0.346$ & $2.204 \pm 0.485$ & $2.601 \pm 0.481$ \\
Jul-16 & $1.691 \pm 0.347$ & $2.333 \pm 0.640$ & $2.722 \pm 0.543$ \\
Aug-16 & - & - & - \\
Sep-16 & $1.606 \pm 0.340$ & 1.389 & $2.481 \pm 0.232$ \\
Oct-16 & $1.557 \pm 0.196$ & $1.490 \pm 0.289$ & $2.605 \pm 0.222$ \\
Nov-16 & $1.678 \pm 0.115$ & $1.905 \pm 0.640$ & $2.385 \pm 0.404$ \\
Mean condition factor & $1.671 \pm 0.273$ & $1.953 \pm 0.644$ & $2.548 \pm 0.516$ \\
\hline
\end{tabular}

\section{Age structure}

Age was determined by examining about 189 specimens of $L$. niloticus; fishes of age $0+$ and $1+$ year were most abundant in in the three sampling sites, with females abundant than males in Um Aswad (Atbara River) and ElMonaba sites (reservoir). Although males of age $1+$ were more abundant than females in El-Remila site (reservoir), the two sexes were represented in nearly equal numbers in El- Remila and El-Monaba sites (reservoir). Males and females of age 2+ were few in the three sampled sites, with females dominating males in Um Aswad site, while males dominated females at El- Remila and El- Monaba sites. However, males and females of age $3+$ were scarce in the study area especially in the upstream site of El-Monaba (Figure 3). 

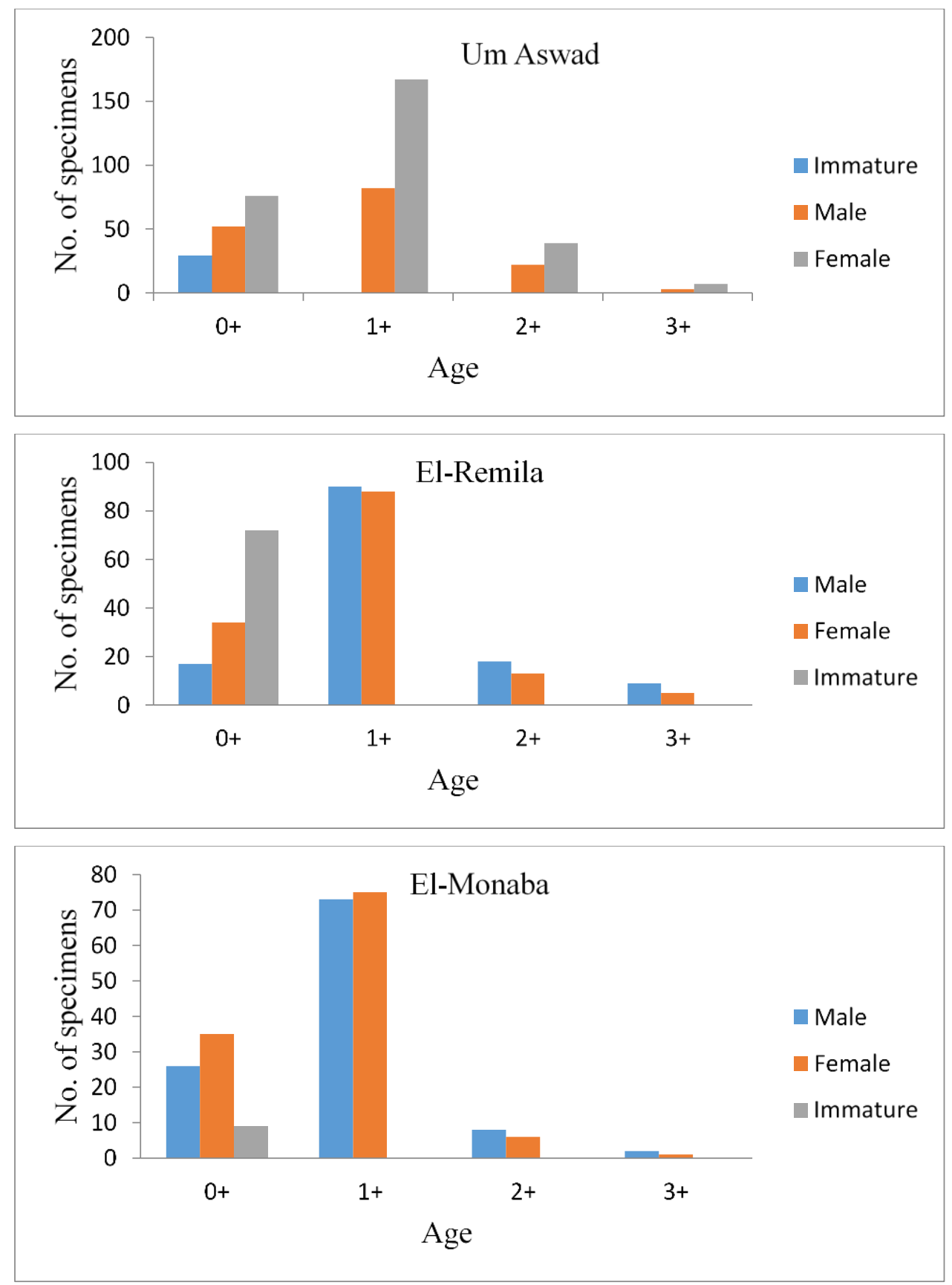

Figure 3. Age structure of L. niloticus in Um Aswad (Atbara River) and El-Remila and ElMonaba (reservoir).

\section{DISCUSSION}

The present study was conducted to determine the lengthweight relationship, condition factor and age structure of Labeo niloticus from Khashm El-Girba reservoir, Sudan. About 1190 specimens of this species were collected from the sampling. Analysis of the regression coefficients obtained indicated negative allometric growth of this species, where the slope (b) of the (LWR) was highly significant $(p<0.001)$ and ranged from 2.178 to 2.885 , suggesting that the length did not increase with the increase in weight of fish in the study area. This result agrees with the findings of Ahmed (2002) who recorded negative allometric growth for $L$. niloticus from five freshwater species in Atbara River and Khashm El-Girba reservoir. Similarly, several authors who worked on $L$. niloticus from the White Nile, Khashm El-Girba reservoir, Atbara River and River Nile within Sudan, reported 
negative allometric growth pattern of this species (Ahmed, 1978; Ibrahim, 2007; Ahmed et al., 2011, Obeida, 2010 and Karar et al., 2017).

The mean condition factor recorded for $L$. niloticus in the study area were $1.671 \pm 0.273 ; 1.953 \pm 0.644$ and 2.548 \pm 0.516 in Um Aswad, El-Remila and El-Monaba sites respectively. Obeida (2010), working on the White Nile, Sudan, reported condition factor $(\mathrm{K})$ mean values of 1.871 , 1.951 and 1.836 for L. niloticus at El- Hashaba, Kosti and El-Nuzul stations respectively. A similar result was obtained by Ahmed et al. (2011) showing that the condition factor $(K)$ of $L$. niloticus ranged from $1.595 \pm 0.912$ to $2.536 \pm 0.070$ in Khasm El-Girba reservoir. On the other hand, Karar et al. (2017) reported that the condition factor for L. niloticus in the River Nile was approximately 1.0. The marked difference in the high values of condition factor recorded in Atbara River and Khashm E-Girba areas compared to that recorded in the River Nile may be due to differences in sampling methods, sample size, seasonal variation in water temperature, turbidity, photoperiod and food availability, in the two freshwater ecosystems.

The dominance of specimens of $L$. niloticus of age $0+$ and age $1+$ in the study area may be due to the use of fishing gear of small mesh size for collecting the fish from the three sampling sites. Soil erosion and heavy siltation of the lentic environment of Khashm El-Girba reservoir during the flood season may have created unfavorable conditions for the growth of large -sized fish. Moreover, the intensive fishing activities carried out before the flushing period of the dam (August) may have resulted in drastic changes in the physical and chemical characteristics of the water, water flow, change in water level and subsequent changes in the food composition of the fish.

\section{Conclusion}

The length weight relationship of Labeo niloticus from Khashm El-Girba reservoir and River Atbara indicated negative allometric growth of the fish, with (b) ranging from 2.178 to 2.885 , while mean condition factor $(K)$ varied between1.671 and 2.548. Most of the fishes collected during the study consisted of immature males and females of age $0+$ and $1+$. It is recommended that further studies should be conducted on the biology of this commercially important species to provide more detailed information for better understanding, management and exploitation of the fisheries of this species in River Atbara and Khashm ElGirba reservoir.

\section{ACKNOWLEDGEMENT}

The authors would like to express their thanks and gratitude to the staff of Zoology Department, Faculty of Science, University of Khartoum; the staff of Khashm ElGirba Fisheries Research Station and Fisheries and
Aquatic Research Center. Thanks are also due to Mr. Mohamed Sharif, Mr. Amjad Abd El-Gafar, Mr. Banaga Abdo, Mr. Ahmed Abu Zaid Ahmed, Mr. El-Tag Mohamed Abdalla and Mr. Hassan El-Tayib, for the unlimited assistance they offered during collection of samples.

\section{COMPETING INTERESTS}

The authors of this paper declare that competing interests do not exist.

\section{REFERENCES}

Abdalla, M. Y. M. (2018). Biological aspects of Oreochromis niloticus and Labeo niloticus from Khashm El-Girba reservoir and Atbara River, Kassala state, Sudan. M. Sc. Thesis, Department of Zoology, faculty of science, University of Khartoum, Sudan.

Abdalla, M. Y. M. Abdelhalim, A. I., \& Adam, A. E., (2020). Study of some biological aspects of the Nile carp, Labeo niloticus (Pisces, Cyprinidae) from Khashm El-Girba reservoir and Atbara River, Sudan: I Abundance; sex ratio; gonado-somatic index and breeding season. Asian Journal of Research in Zoology, 3(3), 21-28.

Abu Gideiri, Y. B. (1984). Fishes of the Sudan. Khartoum University press, Democratic Republic of Sudan, 122p.

Ahmed, A. A., (1978). On the Biology of Cyprinidae fish in northern part of White Nile. M. Sc. Thesis, Department of Zoology, Faculty of Science, University of Khartoum, Sudan.

Ahmed, E. O., Ali, M. E., \& Aziz, A. A. (2011). Length-weight relationships and condition factors of six fish species in Atbara River and Khashm el-girba Reservoir, Sudan. International Journal of Agriculture Sciences, 3(1), 65-70.

Ahmed. E. O. (2002). Studies on the productivity and fisheries of Khashm El-Girba reservoir in relation to annual fishing. M. Sc. Thesis, Department of Zoology, Faculty of Science, University of Khartoum. Sudan.

Bagenal, T. B., \& Tesch, F.W. (1978). Methods of Assessment of Fish Production of Freshwater. IBP Handbook No. 3, 3rd ed. Black-wells, Science Publication, Oxford, London, Edinburgh.

Bailey, R. G. (1994). Guide to the fishes of the River Nile in the Republic of the Sudan. Journal of Natural History, 28(4), 937970.

El-Azrag, N. M. (1981). Some biological studies of the family Characidae in the northern part of White Nile. M. Sc. Thesis, Department of Zoology, Faculty of Science, University of Khartoum, Khartoum, Sudan.

El-Kasheif, M., Authman, M., \& Ibrahim, S. (2007). Study of age, growth and some population dynamics aspects of the Nile Cyprinidae fish, Labeo niloticus, from the River Nile at ElKanater El-Khyria, Egypt. CATRINA: The International Journal of Environmental Sciences, 2(1), 7-21.

El-Moghraby, A. I., Mishrigi, S. Y., \& Kheir, H. (1993). Report on the impact of the flushing of Khashm El-Girba reservoir on fisheries resources and its socio-economic on riparian communities. Sudan Environment, Conservation Society. Pp. 14-33.

Food and Agriculture Organization (FAO) (2014). The state of world fisheries and aquaculture. Food and Agriculture Organization, Rome, Italy. 223p.

Froese, R. (2006). Cube law, condition factor and weight-length 
relationships: history, meta-analysis and recommendations. Journal of Applied Ichthyology, 22(4), 241-253.

Ibrahim, M. A. (2007). Some Aspects of Khashm El-Girba fisheries, Atbara River. M.Sc. Thesis, Department of Zoology, Faculty of Science, University of Khartoum. Sudan.

Karar, A. M. M., El-Bassir, H., Adam, I. I., Eisa, M. A., \& Adam, M. I. (2017) length- weight relationship and condition factor of three commercial fish species of River Nile, Sudan. EC Oceanography, 1(1), 1 -7.

Khallaf, E., Galal, M., \& Athuman, M (2003). The biology of Oreochromis niloticus in a polluted canal. Ecotoxicology, 12, 405-416.

Le Cren, E. D. (1951). The length-weight relationship and seasonal cycle in gonad weight and condition in the perch (Perca fluviatilis). Journal of Animal Ecology, 20(2), 201-219.

Mensah, S. A. (2015). Weight-length models and relative condition factors of nine freshwater fish species from the Yapei Stretch of the White Volta, Ghana. Elixir Applied Zoology, 79, 30427-30431.

Nin, B. M. (1992). Determination of growth in bony fishes from Otolith microstructure. FAO Technical Paper No 322. FAO, Rome, Italy. 51p.

Obeida, M. M., (2010). On the biology and fisheries in Jebel Aulia dam reservoir (El hashaba to Elnuzul) using beach seine net. M. Sc. Thesis. Department of fisheries, Collage of Natural Resources and Environment Studies, University of Juba, Sudan.
Riedel, R., Caskey, L. M., \& Hurlbert, S. H (2007). Length-weight relations and growth rates of dominant fishes of the Salton Sea: implications for predation by fish-eating birds. Lake and Reservoir Management, 23, 528-535.

Salih, E. H. M., (1995). Fishing, flushing and fish behavior- A case study from the seasonal Khashm El Girba reservoir in Sudan (pp. 197 - 211). In: Santbergen \& Van Westen C. J. (eds.). Reservoir in River Basin Development, Balkema, Rotterdam, Netherland.

Schneider, J. C., Laarman, P. W., \& Gowing, H. (2000). Lengthweight relationships, Chapter 17. In: Schneider, J. C. (ed.), Manual of fisheries survey methods II: with periodic updates, Michigan. Department of Natural Resources, Fisheries Special Report 25, Ann Arbor; 2000. Pp. 1-18.

Sparre, P., \& Venema, S. C. (1992). Introduction to tropical fish stock assessment. Part I Manual. FAO Fisheries. Technical. Paper. 306/1. FAO, Rome, Italy.

Yilmaz, S., Yazicioğlu, O., Erbaşaran, M., Esen, S., Nengin, M., \& Polat, N. (2012). Length-weight relationship and relative condition factor of white bream, Blicca bjoerkna (L., 1758). Journal of Black Sea/Mediterranean Environment, 18(3), 380387. 